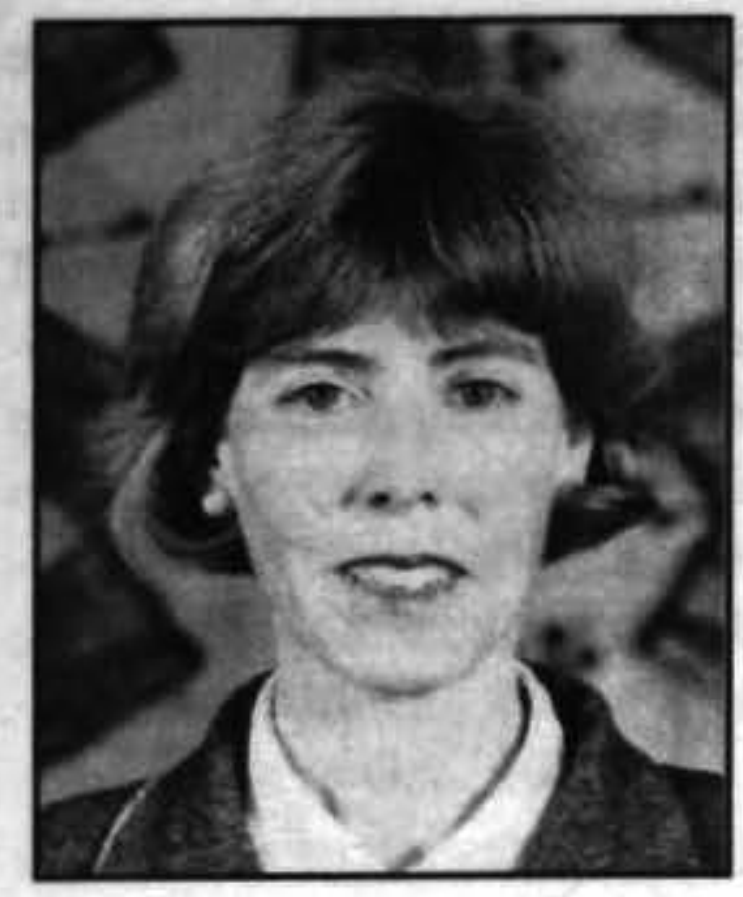

\title{
ABSENTEEISM IN THE SMALL BUSINESS SECTOR
}

\author{
Felicity Lamm
}

\author{
Department of Management \\ and Employment Relations \\ The University of Auckland
}

\section{Abstract}

In spite of the fact New Zealand small businesses represent over 90 percent of the business population there has been little research and scant discussion regarding absenteeism in small businesses. The implication is that absenteeism in the small business sector is similar to that experienced by large businesses and therefore does not warrant special attention. Based on data gathered from 65 New Zealand small business case studies since 1990 onwards, this paper attempts to outline the issues surrounding absenteeism in the smalt business sector within the context of the ECA employment environment. It is understood that any discussion on absenteeism cannot be separated from the employment issues surrounding worker injury and illness as one is the consequence of the other. It is also argued that worker absenteeism in small businesses is the action of last resort for the following reasons: lack of compliance and enforcement small business employment practices; precarious employment and the employment environment.

\section{Keywords: Compliance, enforcement, small business, employment practises, absenteeism}

Studies suggest that workers in small businesses are experiencing a higher percentage of injuries and ill health than previously thought (Eakin \& Semchuk, 1988; Eakin, 1992; Eakin, et al; Mayhew, 1997, 1999; Quinlan, 1993, 1998, Lamm 1999a,b) and that the small business sector has a lower OHS (occupational health and safety) compliance rate compared with the medium-sized and large business sectors (Bickerdyke \& Lattimore, 1997, Lamm, 1992, 1999a). Moreover, in spite of the fact New Zealand small businesses represent over 90 percent of the business population and approximately 60 percent of the workforce (Statistics New Zealand, 1999a,b; New Zealand Department of Labour, 1999b) there has been little research and scant discussion regarding absenteeism in small businesses. The implication is that absenteeism in the small business sector is similar to that experienced by large businesses and therefore does not warrant special attention.

Based on data gathered from 65 New Zealand small business case studies since 1990 onwards, this paper attempts to outline the issues surrounding absenteeism in the small business sector within the context of the current employment environment. It is understood that any discussion on absenteeism cannot be separated from the employment issues surrounding worker injury and illness as one is the consequence of the other. It is also argued that worker absenteeism in small businesses is the action of last resort for the following reasons: lack of compliance and enforcement; small business employment practices; precarious employment; employment environment.

For the purpose of this paper, small businesses in the nonmanufacturing sectors are described as having fewer than 20 employees, while small businesses in the manufactur- ing sector are described as having fewer than 100 employees (Australian Bureau of Statistics \& New Zealand Department of Statistics, 1993).

\section{OHS Compliance and Enforcement in the Small Business Sector}

The rate of occupational injury and illness and the subsequent absenteeism in the small business sector is influenced by the level of enforcement and the ability of the small business employer to comply with the OHS regulations. There is no doubt that providing a safe and healthy working environment will reduce the level of absenteeism and the need to workers to continue working while ill or injured. However, research shows that meeting OHS requirements and employment regulations in general, are more difficult for small businesses than for medium-sized and large businesses (Homewood, 1982; Hutter, 1998; Scott et al, 1989; Khan, 1993; Lamm, 1992, 1998). There is a suspicion that while large and medium-sized businesses have been able to keep abreast with the changes in OHS law, small businesses have not. The resources that larger businesses have at their disposal to implement regulatory changes and to maintain existing ones cannot be matched by smaller firms. Unlike large businesses, conforming to the regulations often places a greater financial obligation on small businesses as they are unable to spread their compliance costs over a number of products, markets or plants (Hoy \& Vaught, 1980; Franklin \& Goodwin, 1983; Khan, 1993, Holliday, 1995). This puts the smaller firm at a distinct disadvantage.

There is also widespread dissatisfaction among small busi- 
ness employers as they believe they have not been consulted by government legislators (Bollard, 1988; MacMillan et al, 1989; Scott et al, 1989; Khan, 1993; Woolfson, 1995). The overriding issue for those in the small business sector is that regulations are conceived without any thought being given to whether or not they can cope with the new or changed regulations. Extensive legislative reforms over the last decade have in fact resulted in an increase in new legislation which has further encumbered small businesses. When questioned on burden of compliance with current legislation, 97 percent of New Zealand employer respondents ranked the Employment Contracts Act, 1991, as the most burdensome, with occupational health and safety (96 percent) second most burdensome, compared with the goods and services tax, which was ranked fifth (New Zealand Herald, 1998). It must be noted that responses varied depending on the level of financial burden of compliance experienced by the employer, and whether or not the small business operated in a hazardous and highly regulated industry. Table 1 illustrates the range of small business employer responses to the OSH Service. The high number of neutral response is indicative of the lack of personal contact the employer has with the OHS inspectorate, as can be seen in Table 2 .

\section{Table 1. NZ Employers' Responses to the OSH Service}

\begin{tabular}{cc}
\hline Employer Responses & $\begin{array}{c}\text { New Zealand Case } \\
\text { Studies }(\mathbf{n}=\mathbf{6 5})\end{array}$ \\
\hline Negative & 16 \\
Neutral & 29 \\
Positive & 20 \\
\hline
\end{tabular}

\begin{tabular}{ccc} 
Table 2. & $\begin{array}{c}\text { Number of visits by NZ OHS } \\
\text { Service Inspections }\end{array}$ \\
\hline & $\begin{array}{c}\text { New Zealand } \\
\text { Case Studies } \\
\text { (n=56) }\end{array}$ & $\begin{array}{c}\text { New Zealand } \\
\text { Case Studies } \\
\text { (n=65) }\end{array}$ \\
\hline Years & $\begin{array}{c}\text { Most recent } \\
\text { contact }\end{array}$ & $\begin{array}{c}\text { Number of } \\
\text { Visits }\end{array}$ \\
\hline 0 & 22 & 22 \\
$1-11$ months & 4 & - \\
$1-2$ & 2 & 13 \\
$3-4$ & 11 & 16 \\
$5-6$ & 10 & 6 \\
$7-8$ & 6 & 4 \\
$9+$ & 1 & 4 \\
\hline
\end{tabular}

One of the primary reasons for the lack of contact between the OHS inspectorate and the small business sector is the legacy of past governments which have systematically reduced the funding to the OSH Service and gradually withdrawn their support for state controlled workers' injury compensation. Decades of government disengagement of workers' health and safety has been a slow drift in which the OHS Service has, according to public documents, suffered an average annual cut of 1.5 percent since 1987 (although government officials maintain that the Service has had a net funding increase of 37 percent), while at the same time being expected to provide an extended service to a growing business population. In addition, there has been a decline of almost 40 percent in the number of OHS staff from 1987 to 1998 , with a ratio of one inspector to approximately 20,000 businesses. It is interesting to note that the International Labour Organisation (ILO) sets a ratio of one inspector to 200 business units (New Zealand Department of Labour, 1998, 1999a,b; Campbell, 1998; Lamm, 1996, 2000).

With the reduction in OSH Service resources and staffing levels, there has been an antithetical increase in the number of small business. However, the small business sector is difficult to regulate as it is heterogeneous and geographically scattered. In addition, there is growing evidence that the small business sector has a lower compliance rate than is the case in the large business sector (Mayhew \& Quinlan, 1998; Lamm, 1999). Case study data indicates that only a quarter of those interviewed had a copy of the Act, as seen on Table 3.

\section{Table 3. Compliance Responses by New Zealand Small Business Employers}

\begin{tabular}{ll}
\hline New Zealand Case \\
Study Responses \\
$(n=65)$
\end{tabular}

\begin{tabular}{ll}
\hline Has a copy of the Act & $25(38 \%)$ \\
Does not have a copy of the & $24(37 \%)$ \\
$\begin{array}{l}\text { Act } \\
\text { 'No Act cited }\end{array}$ & $16(25 \%)$ \\
Is aware of the duties under & $43(66 \%)$ \\
Act & $22(34 \%)$ \\
Is not aware of duties under \\
the Act \\
$\begin{array}{l}\text { 1. The researcher was unable to verify if the employer } \\
\text { had a copy of the OHS Act. }\end{array}$
\end{tabular}

If it is the case that New Zealand OHS inspectors are unlikely to inspect most small workplaces, how does this affect workers in the small business sector, given that most are predominantly non-unionised, precariously employed and non-English speaking (Buuljens, 1994). First, case study evidence shows that it is often impossible for most workers to place a complaint with the authorities as the close employer-employee working arrangements inhibit any dissension. However, the reasons for this differ; either the worker felt a sense of loyalty to the employer (to whom they may be connected either by family or friendship ties) or the worker feared possible employer reprisals. Second, most workers interviewed had idea which government department to contact regarding employment issues, such as OHS. Third, many non-English speaking workers faced another barrier as their were unable to communicate with the staff from the OHS regulatory agency. Fourth, for some workers, particularly those originating from countries with harsh political regimes, government departments are to be avoided. Fifth, there is virtually no trade union presence 
in the small business sector to act as a representative for the worker over OHS matters. This is not surprising given that the present OHS law deviates from the Robens model in that it does not stipulate the need for participation by employees or trade unions in the decisions affecting their health and safety. Therefore, it is difficult to see how reducing the staff and resources of OSH Service and Labour inspectorate and lessening contact between workers in the small business sector and the OHS regulatory agency will aid the health and safety of workers in small businesses (refer also to Gun, 1992).

\section{Employment in the Small Business Sector}

Studies show that small businesses are less likely to adopt formalised employment or OHS procedures (Purcell \& Gray, 1986; Callus et al, 1991; Lamm 1999a) and that 85 percent of small business respondents employ no union members (Sappey, 1985; Buultjens, 1994). While there is still controversy regarding whether or not the small business sector plays an important part in generating jobs (Birch, 1987; Storey, 1994) researchers have been critical about the quality of employment (Curran \& Stanworth, 1981a,b; Rainnie, 1989; Scott et al, 1989; Isaac, 1993; Quinlan, 1993; Williams, 1993; Buultjens, 1994). The studies show that in small businesses are predominately nonunionised (Buultjens, 1994) and that wage rates are often lower, jobs less secure (Harbridge \& Street, 1994, Brosnan \& Walsh, 1998) and working conditions poorer (although job satisfaction is frequently higher than in large companies) (Sappey, 1983, 1985; Bollard, 1988; Dawson et al, 1988; Kitay \& Sutcliffe, 1989; Scott et al, 1989; Isaac, 1993; Buultjens, 1994; Blyton \& Tunrbull, 1998). As a result there is growing apprehension among unions, regulatory agencies and researchers regarding the welfare of employees in small businesses.

While the above employment relations literature acknowledges the unique employment characteristics of the small business sector, it is largely ignored by the OHS literature, with a few exceptions such as Eakin, (1992) Nichols et al. (1995), Mayhew et al. (1997), Frick and Walters (1998) and Quinlan et al. (2000) etc. Recent studies undertaken have begun to make important links between small business employment relationships and OHS. It is argued, therefore, that an investigation of small business employment relations is relevant to the overall topic.

Analysis of the case study data reveals that an increasing number of small business employers are hiring people with whom they are already acquainted, rather than recruiting strangers. According to the employers interviewed, dismissal procedures that favour employees are forcing employers to hire either their friends or family members. Another reason why the practice of hiring family and friends is popular among small businesses is that it lessens the likelihood of recruiting people who have undisclosed chronic injuries or illnesses, and thus reduces the chances of absenteeism and/or of having a worker filing a compensation claim against the employer.
Employing family or friends in a small workplace can influence the standard of OHS in either a detrimental or a beneficial way. The research shows that small business employers appear to trust their family members and friends to work safely and are reluctant to supervise or instruct them in OHS matters. There is also evidence that the collective culture of the family firm has an influence on how absenteeism is viewed. As other 'group' studies show, (eg Ryan, 1996) absenteeism is seen by workers as letting their team down which has the effect of compelling the worker to attend, irrespective of how ill or hurt they may be. However, more extensive research is needed into the relationship between the small family business culture and absenteeism.

Many of those working in the small business sector are women. While data indicates that women workers have different experiences from complete autonomy to virtually none, the outcomes of absenteeism are similar. One on hand, the women who felt exploited and had little control over their working environment, stated that they were reluctant to take more than a day off at a time for fear of loosing their job. These women were often married with small children, often working illegally, had little or no English and were paid well below the minimum wage. Absenteeism among these workers was more likely to be as a result of having to care for a family member, rather than taking time off work to convalesce. On the other hand, the women who had autonomy and discretion over their working conditions felt obliged to attend work irrespective of their own well-being. While the extant literature has given little attention to the gender differences between male and female workers in the context of OHS in small businesses, consideration must be given to the possible different experience of absenteeism that occur between male and female workers.

Not only is the employment of women in small businesses frequently overlooked in the discussion on absenteeism. but also the role of social and cultural norms in determining the level of absenteeism. However, as there is some reference to the influence of social and cultural norms on OHS in small businesses (refer Eakin 1992; Kelly et al, 1996; Martin et al, 1996), it was decided to draw attention to the personal characteristics of a small business employer and employee in the investigation of absenteeism in small businesses. In addition, it became apparent that some phenomena concerning OHS in the small business sector could only be explained in terms of the social and cultural norms of the individuals concerned. For example, when discussing OHS regulatory compliance, and employment practices, employers and employees made frequent reference to the way in which their country or state of origin influenced their approach to the health and safety of their employees. However, more research is required in this area before any definitive statements can be made.

\section{Precarious Employment}

As a result of labour market reforms commencing in the late 1980 s, New Zealanders have seen a reversal in condi- 
tions and wages, for example the withdrawal of penal rates, the dismantling of industry-specific safety provisions and the erosion of limits on hours of work, etc (Harbridge \& Street, 1994; Rasmussen \& Lamm, 1999). Additionally, many vulnerable employees are not aware of their rights (Gleisner \& Rasmussen, 1995). The case studies reflect the shift in the labour market from full-time, permanent employment to precarious employment, with an increase in part-time, temporary and casualized workers (refer to Mayhew \& Quinlan, 1997b; Burgess, 1997; Burgess \& Campbell, 1998; Brosnan \& Walsh, 1998). According Burgess (1997:85), between 1984 and 1994 the number of Australian casual employees has almost doubled, increasing from 848,000 to $1,579,000$. Burgess also notes that in 1994 Australian women accounted for 60 percent of casual employees. Although the New Zealand Department of Statistics has no figures on exactly how many workers have been casualized since 1991, there has been a 6 percent increase in the number of part-time workers between January 1998 and March 1998. Academics and trade unionists argue that there is a comparable trend in New Zealand of casualizing the workforce and reducing the hours of full-time workers. More importantly, there are the negative implications of precarious employment on OHS, as outlined in Mayhew and Quinlan's report, 'Outsourcing and Occupational Health and Safety' in which they state:

... the growth of outsourced labour has un-
dermined OHS and other working condi-
tions of all workers ... The growth of
outworking has significant implications for
industrial regulation, trade unions, employ-
ment conditions, the externalisation of in-
jury costs, and for government and society
as a whole (1998:132).

It is argued that the trend in precarious employment practices is triggered by a desire to reduce the wage and compliance costs associated with employment, which is estimated to be on average one-third to one-half of a small business' outgoings (Cameron \& Massey, 1999). It was not surprising to find that small business employers were continually seeking ways of minimizing these costs, which, if undertaken, were likely to result in the reduction of wages and poorer conditions for workers. The findings highlighted the following six strategies used by small business employers to reduce their labour and compliance costs:

- $\quad$ the use of temporary labour;

- $\quad$ the use of casualized labour;

- the use of illegal migrant labour;

- the conversion of full-time employees into selfemployed

- $\quad$ outsourcing work;

- the use of low-paid trainees; and

- the replacement of male full-time workers with female part-time workers.

In the first strategy, the employer establishes a temporary workforce in which workers are employed on a project- by-project basis. This practice was found primarily where the service or production of single-item goods was core business, and occurred in industries ranging from printing to engineering. Under this approach, it was routine for staff to be made redundant, and then re-hired back on a temporary contract basis, often undertaking a variety of tasks. This created major OHS problems for the temporary staff, in which ergonomic problems, such as ill-fitting safety gear, poor work-stations, etc., were especially prevalent in such flexible working environments.

The second strategy involves casualizing the permanent workforce and employing workers when and if there is work available (as opposed to part-time workers who have a regular job but work reduced hours). This is a common practice in the small business sector, particularly in times of economic downturn or when there is a sudden need for extra labour for a short period of time. However, casual labour is typically made up of illegal migrant workers. Over a third of Auckland case studies use illegal migrant casual workers instead of permanent or temporary staff. 'Pimps' in charge of gangs of illegal migrant workers roam the Auckland industrial sites, concentrating only on small businesses, with the intention of supplying them with cheap labour on a day-to-to basis For many Auckland small business employers, this arrangement is a god-send, as it not only reduces their labour costs, but, in their opinion, it relieves them of their legal obligations under employment law, thus ensuring the survival of their business. This arrangement also has direct and indirect consequences for OHS in small workplaces. In most instances, it was observed that the illegal migrant workers undertook dangerous and/or tedious tasks, with little or not regard given to OHS. However, it must be noted that some employers voiced concerns regarding the widespread use of illegal migrant workers. They argued that such an employment strategy not only undermines the competitiveness of those law-abiding businesses, but also has the affect of reducing wages and conditions even further in the small business sector and thus making it more difficult to attract high quality labour (refer also to Hedge, et al. 1999)

The third strategy involves converting permanent employees into 'self-employed' individuals. That is, the employer dismisses his/her workers and promptly 're-hires' them back but as self-employed sub-contractors. These 'selfemployed' workers (refer Vandenheuvel \& Wooden, 1995) or 'entrepreneurial' workers (refer Rasmussen and Deeks, 1998) are only paid when and if work is available and are not afforded the same protection as other employees under current New Zealand employment law, including OHS. In some cases the employer will insist that the 'self-employed' worker buys some or all of the machinery and pays the employer rental for the use of the premises. These employers explained that by making their workers 'selfemployed' they not only devolved themselves of all the paraphernalia that goes with hiring staff, such as paying taxes, complying with the employment laws, etc, but their workers also benefited by opting out of 'the government's clutches' (why this would benefit employees was never explained). 
The fourth strategy is outsourcing work, which has the effect of not only reducing permanent staff, but also lessening OHS compliance costs. As with larger companies, small businesses dispense with certain employment and compliance costs by passing them on to other businesses. This was particularly evident in the manufacturing and construction industry sectors, in which 9 percent of small business managers elected to contract out the hazardous processes when faced the with expensive corrective modifications dictated by OHS regulations. As Mayhew and Quinlan point out:

The shift to outsourced labour entails a simultaneous process whereby occupational injuries vanishes from the official record and the costs associated with them are externalised (1998:133).

Another reason given to outsource work was the implementation of quality standards, where accreditation rests on the control and/or elimination of hazards. Dangerous activities that obstructed the accreditation process were outsourced to other small businesses. It was described by one interviewee as:

As a win-win situation, where we become accredited and get the lucrative contracts and in turn pass on the risky part of the job to the other firm who are more geared up to doing that sort of work ( $274 \mathrm{q} 8 \mathrm{sp})$.

The fifth strategy involves employing trainees to work either for a non-payment-for-experience basis or for a trial period, with no prospect of continuous employment (often unbeknown to the trainee). Trainees, unable to gain paid work because of their inexperience, either approach an employer, or vice versa, to work for a period without wages in order to gain relevant work experience. In some instances, although the employer enters the arrangement on the understanding that the worker will not be paid, often the employer relents and pays the workers the minimum wage.

A minority of New Zealand small business employers took on trainees on a 'trial basis' on low wages with the promise of permanent work and higher wages once the trial period had been satisfactorily completed. However, in these instances, the employer had no intention offering the trainee permanent work or a promotion. At the end of the trial period (which in some cases was be extended), the trainee was made redundant or dismissed on the grounds of 'unsatisfactory' work and shortly thereafter a new trainee was taken on. As one small business employer, who used this strategy, stated:

I know what I am doing is a ticking time bomb. Every time I make one kid redundant and then take on another one I' $m$ running the risk of one smart guy taking me to court over the so-called 'redundancy (accountantnz12).

There are several OHS implications associated with this strategy. According to OHS inspectors, young workers have a high incident of work-related injuries and fatalities. Using unpaid or low paid young trainee workers creates problems in enforcing OHS laws, particularly where workers are employed on a voluntary basis. In addition, processing workers' compensation claims, where payments are based on individual earnings, disadvantages such trainees.

The sixth strategy involves supplanting full-time male workers with female part-time, temporary or casual workers. The impact of this strategy on labour in small workplaces is profound, as wages and conditions appear to deteriorate, and has the potential effect of defusing the employer's duty of care (Harbridge \& Street, 1994). There was a perception among some employers that a predominately non-unionized, precariously employed female workforce is less likely to complain over wages and conditions than a unionized male, permanent, full-time workforce. Also, for those in precarious employment it becomes problematic when seeking redress over breaches of OHS law or obtaining workers' compensation, as establishing when and how the injury or illness occurred is difficult. As one interviewee, who sustained an occupational over-use injury (OOS) while at a previous job, stated:

It was really hard to get anyone to believe me that $X$ printing company was responsible for the OOS. The boss just turned around and told them /Accident Compensation Corporation] that I definitely didn't get it working for him and that I got it in my other jobs or most probably I got it at home gardening or something like that. I mean to say, of course it had nothing to do with the fact that I worked 12 hours a day for three-andhalf- months, without a break, to get his bloody job done.

\section{Employment Environment}

As emphasised earlier, in order to understand worker absenteeism we need to understand the employment environment. The present New Zealand employment environment has created added pressures for the workforce. People are working longer and harder, in which the upward pressure on working time has seen the 40-hour week becoming less prevalent (Rasmussen \& Lamm, 1999, Rasmussen et al, 2000). In addition, provisions under the Holidays Act, 1981 for three weeks annual leave plus 11 days statutory holiday were under attack by the 1990-1999 National Government with support by the Business Roundtable who question the need for Government to set any holidays at all (Macfie, 1998). While the debate about casualisation has focused on people working less than 40 hours per 
week, it may be just as worrying that many people are increasing their working hours to over 50 or 60 hours on average per week (Statistics New Zealand 1999b).

Stress related injuries and illness are now common. For example there has been a 40 percent increase in workers compensation claims for occupational over-use syndrome (OOS) injuries between 1994 and 1996. The OOS compensation claims for 1996 cost New Zealand ACC $\$ 9.7$ million, as shown in Table 4 OOS injuries are not concentrated in one particular industry but are spread across a wide range of processes, from the meat industries to the financial sector. The largest increase in claims since 1994 has come from those workers in administrative occupations (154 percent increase between 1994-1996) and 34 percent of new claims for OOS in 1997 were made by men (New Zealand Accident Compensation Corporation, 1998). It should be noted that OOS was introduced as a distinct injury code for the diagnosis field in the ACC database from July 1992. Prior to that the OOS condition was either coded under a "sprain or strain" or was not included in the database on the basis of its earlier classification as an illness and if diagnosed as an illness, victims could not claim compensation under the ACC regulations. Moreover, the most recent ACC data on OOS shows a decline in the number of claims in 1997. This decline may have more to do with the introduction of a stricter ACC assessment criteria for OOS, rather than a decline in the number of individuals experiencing OOS. It is also thought that the stricter criteria has had an affect on the OOS related absenteeism, as workers are less inclined to take time off to recuperate if they are not receiving any compensation.

Although the link between hours worked, ill health and injuries is still debatable, there is growing evidence that working beyond 48 hours a week doubles the risk of coronary heart disease (Wedderburn, 1996; Smith, 1999; Bohle \& Quinlan, 2000). Similarly, a New Zealand study by O'Driscoll reveal that as daily working hours are increased from eight to 12 , there are detrimental effects on health and safety over time (cited Macfie, 1998). Other New Zealand studies on shift work show that people who cope better are those with well-established community and family support networks, maintained during periods outside work. These studies argue that lessening the provisions under the Holidays Act, 1981, will therefore, detrimen- tally effect the lives of shift workers (Veale, 1994; Wilson, 1994; Rasmussen \& Lamm, 2000)

Is there any sign of improvement in New Zealand? Wren (1998) argues that given the present weak institutional structures and a laissez-faire legislative framework that promotes flexibility in the labour market at all costs, the future of workers' health and safety and adequate workers' compensation are at risk. He gloomily predicts that:

\begin{abstract}
Working hours would increase as would the intensity of work. Holiday and sick leave entitlements would decline. Employer control would become more arbitrary, and labour would be cheap and easy to replace. Workers would continue to have no say over decisions about their health and safety, and the OSH Service would continue to be under-resourced irrespective of the political party in power (1998c:6).
\end{abstract}

\section{Conclusion}

It is evident that the unique employment arrangements in the small business sector influences the level of worker absenteeism. However, as we have seen worker absenteeism is more complex than simply 'taking time off' as a result of an injury or illness, particularly in the small business sector. For many New Zealand workers 'taking time off' is not option for a variety of reasons, such as: a sense of loyalty toward those working in the small business, fear of loosing one's job or causing offence and the lack of remuneration or compensation. While the current employment law does allow workers not only to take sick leave, but to expect to work in a healthy and safe working environment, enforcement of the regulations is rare in the small business sector. Moreover, the present employment environment with the increase in the level of unemployment, the rising number of workers in precarious and hazardous employment, the unwillingness of governments to resource the OHS and Labour regulatory enforcement agencies and the general lack of commitment to prevention will do nothing to stem the rise in work-related fatalities, injuries or illnesses in New Zealand.

\section{Table 4. Number and Cost of New ACC Entitlement Claims for OOS for the}

Financial Year 1994-1997

\begin{tabular}{lllll}
\hline & $\mathbf{1 9 9 4}$ & $\mathbf{1 9 9 5}$ & $\mathbf{1 9 9 6}$ & $\mathbf{1 9 9 7}$ \\
\hline $\begin{array}{l}\text { Number of new } \\
\text { claims }\end{array}$ & 3,292 & 5,840 & 8,212 & 6,296 \\
$\begin{array}{l}\text { New cost } \\
\text { New earnings-related } \\
\text { compensation }\end{array}$ & $\$ 4.3$ million & $\$ 6.9$ million & $\$ 9.7$ million & $\$ 8.0$ million \\
\end{tabular}

(Source: Accident Compensation Corporation. 1998) 


\section{Future Research}

Although the study has highlighted factors influencing employee decisions concerning sick and domestic leave, the findings relate primarily to urban small businesses situated in Auckland. That is, the case study sample is representative of Auckland's multi-cultural and diverse migrant demography. In addition, the case study is only representative of the following industry sectors: manufacturing, construction services, wholesale and retail trades and property and business services, and did not include other services such as transport, agriculture and forestry. Therefore, there is a need for more indepth research that not only investigates the absenteeism in small businesses located in rural and regional areas, but also includes other prominent industry sectors.

\section{References}

Australian Bureau of Statistics and New Zealand Department of Statistics (1993) Australian and New Zealand Standard Industrial Classification. Canberra: Australian Government Publishing Service.

Bickerdyke, I. and Lattimore, R. (1997) Reducing the Regulatory Burden: Does Firm Size Matter? Staff Research Paper, Industry Commission, Melbourne.

Birch, D. L. (1987) Job Creation in America: How Our Smallest People Put Most People to Work. New York: Free Press.

Blyton, P. and Turnbull, P. (1998) Employment Relations. London: MacMillan Press.

Bohle, P. and Quinlan, M. (eds) (2000) Managing Occupational Health and Safety in Australia: A Multidisciplinary Approach. Melbourne: Macmillan.

Bollard, A. (1988) Small Business in New Zealand. Wellington: Allen \& Unwin-Port Nicholas Press.

Brosnan, P. and Walsh, P. (1998) Employment Security in Australia and New Zealand. Labour and Industry. April, 8 (3): 23-42.

Burgess, J. (1997) The Flexible Firm and the Growth of Non-standard Employment. Labour and Industry. 7 (3): 85-102.

Burgess, J. and Campbell, I. (1998) The Nature and Dimensions of Precarious Employment in Australia. Journal of Labour and Industry. April, 8 (3):5-22.

Buultjens, J. (1994) Labour Market Deregulation: Does Small Business Care? International Journal of Employment Studies, 2 (1):133-157.

Callus, R. Morehead, A. Cully, M. and Buchanan, J.
(1991) Industrial Relations at Work - The Australian Workplace Industrial Relations Survey. Canberra: Commonwealth Department of Industrial Relations.

Cameron, A. and Massey, C. (1999) Small and Mediumsized Enterprises: A New Zealand Perspective, Auckland: Longman.

Campbell, I.B. (1998) Health and Safety in Employment Act: an Overview. Palmerston North: Uni-Osh Publishing.

Curran, J. and Stanworth, J. (1981a) Size of Workplace and Attitudes to Industrial Relations in the Printing and Electronics Industries. British Journal of Industrial Relations. 19 (1): 14-25.

Curran, J and Stanworth, J. (1981b) The Social Dynamics of the Small Manufacturing Enterprise. Journal of Management Studies, 18 (2):141-58.

Dawson, S. Willman, P. Clinton, A. and Bamford, M. (1988) Safety at Work: The Limits of Self-regulation. Cambridge: Cambridge University Press.

Eakin, J. (1992) Leaving It Up To The Workers: Sociological Perspective on the Management of Health and Safety in Small Workplaces. International Journal of Health Services. 22 (4): 689-704.

Eakin, J. Lamm, F. Limborg, H. (1998) International Perspective on thePromotion of Health and Safety in Small Workplaces. International Workshop, Policies for Occupational Health and Safety Management Systems and Workplace Change, Amsterdam.

Eakin, J. and Semchuk, K. (1988) Occupational Health and Safety in Small Businesses. Occupational Health and Safety Heritage Grant Program. Toronto: University of Toronto.

Franklin, S.G. and Goodwin, J.S. (1983) Problems of Small Business and Sources of Assistance. Journal of Small Business Management. April, 21: 512.

Frick, K. and Walters, D. (1998) Worker Representation on Health and Safety in Small Enterprises: Lessons from a Swedish Approach. International Labour Review. 137 (3).

Gleisner, J. and Rasmussen, E. (1995) Male Part-time Work and Unemployment: Issues and Trends. The Proceedings of the Third Annual Conference of the International Employment Association. University of Waikato. July, 12-14: 22-33.

Gun, R.T. (1992) Regulation or Self-regulation: Is Robens-style legislation a formula for success? Australian and New Zealand Journal of Occupational Health and Safety. 8 (5):383-388. 
Harbridge, R. and Street, M. (1994) Labour Market Adjustment and Women in the Service Industry: A Survey', New Zealand Journal of Industrial Relations, 20(1):23-34.

Hedge, S. Punja, P. and Lamm, F. (1999) Awareness of OSH Amongst New Migrants to New Zealand. Paper presented at The $6^{\text {th }}$ Annual Conference of Australian and New Zealand Occupational Health and Safety Educators, Auckland.

Holliday, R. (1995) Investigating Small Business Firms: Nice Work? London: Routledge.

Homewood, J. (1982) OH Services to Small Businesses. Occupational Health. 34(4):180-187.

Hoy, F. and Vaught, B. (1980) The Rural Entrepreneur: A Study in Frustration. Journal of Small Business Management. January, 18: 19-24.

Hutter, B.M. (1989) Variations in Regulatory Enforcement Styles. Law \& Policy. 11 (2): 153-174.

Isaac, J.E. (1993) Small Business and Industrial Relations: Some Policy Issues. Melbourne: Centre for Industrial Relations and Labour Studies.

Kelly, M. Barker, S. and Martin, J. (1997) Occupational Health and Safery of Non-English Speaking Background Employees: A Needs Assessment Report. Sydney: Western Sydney Area Health Promotion Centre.

Khan, R. (1993) The Effect of Government on Small Businesses. Department of Management Systems. , Palmerston North: Massey University.

Kitay, J. and Sutcliffe, P. (1989) Employers and Employment Relations in Small Business in Australia. M. Bray and Kelly, D. (eds) Australasian Industrial Relations. Sydney: AIRAANZ.

Lamm, F. (1992) Persuasion or Coercion - Enforcement Strategies in Occupational Safety and Health. Deeks, J. and Perry, N. (Eds) Controlling Interests: Business, the State and Society in New Zealand. Auckland: Auckland University Press:56-176.

Lamm, F. (1996) Small Business Response to the Health and Safety in Employment Act 1992, Submission to the Inquiry into the Administration of Occupational Safety and Health Policy. Wellington: House of Representatives.

Lamm, F. (1999a) Occupational Health and Safety in Australian Small Businesses: What can be done to reduce the lack of awareness and raise the level of compliance in Australian small businesses. UNSW Studies in Australian Industrial Relations, The University of New South Wales.
Lamm, F. (1999b) OHS in Small Businesses: Australian and New Zealand Comparison. Paper presented to the $6^{\text {th }}$ Annual Conference of Australian and New Zealand Occupational Health and Safety Educators, Auckland.

Lamm, F. (2000) 'Occupational Health and Safety Regulation: A New Zealand Perspective', in Bohle, P. and Quinlan, M. (eds) Managing Occupational Health and Safety: A Multidisciplinary Approach. Melbourne: MacMillan.

Macfie, R. (1998) More Work and Less Play', Safeguard, March-April:18-21. MacMillan, Keith, Curran, James, Downing, Steven and Turner, Ian (1989) Consultation with Small Business, Research Paper No. 66. London: Department of Employment.

Mahmood, M. (1994) Small Business and Employment in Australia. 7th Small Enterprise Conference, Auckland.

Martin, J. Kelly, M. Barker, S. and Leibrandt, L. (1996) Industrial Injury Prevention: Development and Evaluation of Resources for Non-English Speaking Background Employees. Sydney: Western Sydney Area Health Promotion Centre.

Mayhew, C. (1997) Barriers To Implementation of Known Occupational Health and Safety Solutions in Small Businesses. Sydney: Division of Workplace Health and Safety and National Occupational Health and Safety Commission.

Mayhew, C. (1999) Identifying Patterns of Injury in Small Businesses: Piecing Together the Data Jigsaw. Mayhew, C. and Peterson, C. (Eds.) Occupational Health and Safety in Australia. Sydney: Allen \& Unwin.

Mayhew, C. and Quinlan, M. (1997a) The Management of Occupational Health and Safety Where Subcontracters are Employed. Journal of Occupational Health and Safety - Australia and New Zealand, 13 (2): 161-169.

Mayhew, C. and Quinlan, M. (1997b) Trucking Tragedies: Why Occupational Health

and Safety Outcomes are Worse for Subcontract Workers in the Road Transport Industry. Working Paper Series 114. School of Industrial Relations and Organisational Behaviour, Sydney.

Mayhew, C. and Quinlan, M. (1998) Outsourcing and Occupational Health and Safety: A

Comparative Study of Factory-based and Outworkers in the Australian TCF Industry. Industrial Relations Research Centre. Sydney: University of New South Wales. 
Mayhew, C. Young, C. Ferris, R. and Harnett, C. (1997) An Evaluation of the Impact of Targeted Interventions on the OH\&S Behaviours of Small Building Industry Owners/Managers/Contractors. Canberra: Division of Workplace Health and Safety and $\mathrm{Na}$ tional Occupational Health and Safety Commission,

New Zealand Accident Compensation Corporation (1992-1998) Injury Statistics. Wellington: Accident Compensation Corporation.

New Zealand Department of Labour (1998). Submission to the Select Committee Hearing on Regulations, July. Wellington: House of Representatives, Government Printing Office.

New Zealand Department of Labour (1999a) The Report of the Department of Labour of the Year Ended 1998, House of Representatives. Government Printing Office, Wellington.

New Zealand Department of Labour (1999b) Summary of OSH Statistics. Department of Labour, Government Printing Office, Wellington.

New Zealand Health and Safety in Employment Act, 1992. Government Printing Office, Wellington.

New Zealand Labour Committee for New Zealand House of Representatives (1996) inquiry into the Administration of Occupational Safety and Health Policy. Standing Order 251, New Zealand House of Representatives, Government Printing Office, Wellington.

Nichols, T. Dennis, A. and Guy, W. (1995) Size of Employment Unity and Injury Rates in British Manufacturing: A Secondary Analysis of WIRS 1990 Data. Industrial Relations Journal. 26 (1): 45-56.

Purcell, J. and Gray, A. (1986) Corporate Personnel Departments and the Management of Industrial Relations. Journal of Management Studies. 23 (2): 205-23.

Quinlan, M. (Ed.) (1993) Work and Health. Melbourne: Macmillan.

Quinlan, M. (1997) The Toll from Toil Does Matter: Occupational Health and Labour History. Labour History. 73:1-29.

Quinlan, M. (1998) The Implication of Labour Market Restructuring in Industrialised Societies for Occupational Health and Safety. Economic \& Industrial Democracy 20 (3): 427-460.

Quinlan, M. Mayhew, C. Bohle, P. (2000) Contingent Work: Health and Safety Perspective. Paper presented to the Conference on "Just in Time Employed - organisational, psychological and medical per- spectives, Dublin.

Rainnie, A. (1989) Industrial Relations in Small Firms: Small Isn't Beautiful. London: Routledge.

Rasmussen, E. and Deeks, J. (1998) Entrepreneurial Workers - Taking the Rough with the Smooth. Lind, J. (Ed.) Demark and Down Under: Essays on Labour Market Regulation. Loe-serian nr. 17, Department of Social Studies and Organisation, University of Aalborg.

Rasmussen, E. and Lamm, F. (1999) An Introduction to New Zealand Employment Relations. Auckland: Longman Paul.

Rasmussen, E. and Lamm, F. (2000) New Zealand Employment Relations. Bamber, G. Park, F. Lee, C. Ross, P.K. and Broadbent, K. Employment Relations in the Asia-Pacific: Changing Approaches. Sydney: Allen \& Unwin.

Rasmussen, E. Lamm, F. Snelders, B. (2000) New Zealand Deregulation of Employment Relations, Occupational Health and Safety and Social Welfare in the Post 1984 period. van Waarden, F. and Simonis, J. (eds). Deregulating Imperfect Markets: On the role of Institutions on Markets. Amsterdam: Thela Thesis.

Ryan, R. (1996) Workplace reform in New Zealand - The State of Play. Report. IR Centre, Victoria University, Wellington.

Sappey, R.B. (1985) Industrial Relations: A Small Business Perspective. Journal of Industrial Relations. 27 (3): 350-63.

Scase, R. and Goffee, R. (1982) "Fraternalism" and "Paternalism” as Employer Strategies in Small Firms. Day, G. Caldwell, L. Jones, K. Robbins, D. and Rose, H. (Eds.) Diversity and Decomposition in the Labour Market. Aldershot: Gower.

Scott, M. Roberts, I. Holroyd, G. and Sawbridge, D. (1989) Management and Industrial Relations in Small Firms, Research Paper No. 70. London: Department of Employment.

Smith, P. (1999) The Compressed Work Week (CWW) and Longer Shifts. Paper presented to the $6^{\text {th }}$ Annual Conference of Australian and New Zealand Occupational Health and Safety Educators, Auckland.

Statistics New Zealand (1999a) Business Activity Statistics, Catalogue Number 01-406. Wellington: Government Printer.

Statistics New Zealand (1999b) Labour Activity Statistics, Catalogue Number 01-408. Wellington: Government Printer. 
Storey, D.J. (1994) Understanding the Small Business Sector. London: Routledge.

Stranger, R. Forsaith, D. McInnes, E. Petrone, F. Symes, C. and Xydias, M. (1996) Women in Small Business: A Review of Research. A Report by the Flinders University of Australia to the Department of Industry, Science and Tourism. Canberra: Australian Government Publishing Service.

VandenHeuvel, A. and Wooden, M. (1995) Self-employed Contractors in Australia: How many and who are they? Journal of Industrial Relations. 37 (2): 263-280.

Veale, A. (1994) Management of Sleep Apnea, Paper presented to the Sleep, Fatigue, Shiftwork Interest Group. Auckland: University of Auckland.

Wedderburn, A.A.I. (1996) Compressed Working Time: Bulletin of European Studies on Time. No. 10. Dublin: European Foundation for the Improvement of Living and Working Conditions.

Williams, C. (1993) Class, Gender and the Body: The Occupational Health and Safety Concerns of Blue Collar Workers in the South Australian Timber Industry. Quinlan, M. (Ed.) Work and Health. Melbourne: Macmillan.

Wilson, M. (1995) Shifting Gears: The Toll of Shiftwork in New Zealand Manufacturing. Labour Employment and Work in New Zealand, Proceedings of the $6^{\text {th }}$ Conference 24-25 November, 1994, Victoria University, Wellington.

Woolfson, C. (1995) Deregulation: The Politics of Health and Safety. Glasgow: Computer Publishing Unit of the University of Glasgow.

Wren, J. (1998) Where from Here? Safeguard. JulyAugust:16-17.

\section{Author}

Felicity Lamm

Senior Lecturer

Department of Management and Employment Relations

The University of Auckland

Private Bag 92019

Auckland

f.lamm@auckland.ac.nz 